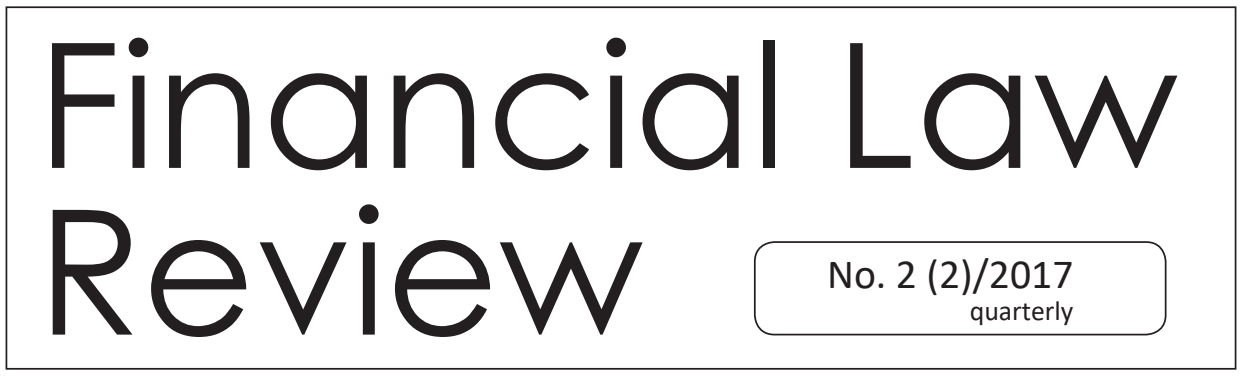

UNIVERSITY OF GDAŃSK • FACULTY OF LAW AND ADMINISTRATION

http://www.ejournals.eu • http://czasopisma.bg.ug.edu.pl

\title{
THE PRINCIPLE OF FISCAL LOCAL AUTONOMY IN THE LIGHT OF POLISH CONSTITUTION ${ }^{1}$
}

Dr Edward Juchniewicz

\section{Summary}

In modern times, the difficult financial situation of municipalities, which are heavily indebted, highlights problem of fiscal local autonomy more than before. It is obvious that for the implementation of the principle of autonomy (principle of independence) of local government is necessary to ensure the financial autonomy (fiscal local autonomy, tax autonomy, proportionality and adequacy of funds) of municipalities. There should be no doubt, that local governments should have enough own funds that can implement the tasks and functions set out in the law. Author of the chapter presents the regulatory and legal problems in terms of the Polish Constitution.

\footnotetext{
1 The article is a reprint of the article originally published in Finansowanie samorządu terytorialnego i jego zadań a Europejska Karta Samorządu Lokalnego. Local government financing and European Charter of Local Self-Government, J. Gliniecka, A. Drywa, E. Juchniewicz, T. Sowiński (red.), CeDeWu Warszawa 2016
} 


\section{Introduction}

There is no other topic more popular at local finance than fiscal local autonomy ${ }^{2}$ or closely related another topic which concerns the issue of revenue sharing between the State and local government units. Regardless of subject area, for example, when the main topic of research concerns issues of tax law, fiscal or banking law, there is always a reference to the principle of fiscal local autonomy. Achievements of science of law and economics in this area continues to grow but does not mean at all that problems in this field in Poland disappear. It could be easily proved by new court decisions, which claim that the problem is not only a theoretical but also practical.

It is obvious that for the implementation of the principle of autonomy (principle of independence) of local government ${ }^{3}$ is necessary to ensure the financial autonomy (fiscal local autonomy) of municipalities ${ }^{4}$. There should be no doubt, that local governments should have enough own funds that can implement the tasks and functions set out in the law. The principle of financial independence of local government suggests that it should regulated by statute that state should provide the municipalities the necessary sources of own revenues sufficient to finance local authorities their expenditure commitments. In theory the conclusion from the context of this principle that if municipalities do not have funds (or do not have enough own funds) to solve local issues they should get financial assistance (subsidies or grants) from the state. Therefore, this is the core issue in this matter, when municipalities are subsidized by the state and consequently they lose their financial autonomy. It is comparable to human beings, that people are not independent financially when they do not have own sources of income. It is worth

\footnotetext{
2 Autonomy - the right or condition of self-government: between the First and Second World Wars, Canada gained greater autonomy from Britain, Oxford Dictionaries, source: http://www.oxforddictionaries.com/definition/english/autonomy [last visited: 12.01.2016].

3 See some thoughts on local government autonomy at J. Ödalen, A Normative Theory of Local Government: Connecting Individual Autonomy and Local Self-Determination with Democracy, Prepared for the American Political Science Association Annual Meeting and Exhibition, August 29-September 1, 2013, Chicago, Illinois. source: https://www.academia.edu/4174425/A_ Normative_Theory_of_Local_Government_Connecting_Individual_Autonomy_and_Local_ Self-Determination_with_Democracy [last visited: 12.01.2016] or see also Michael E. Libonati, Local Government Autonomy, Louisiana Law Review Volume 62 | Number 1 Fall 2001, source: http://digitalcommons.law.lsu.edu/cgi/viewcontent.cgi?article=5914\&context=lalrev [last visited: 12.01.2016].

${ }_{4}$ The problem of analysis of the various principles of law concerns the problems of translation in different languages, use of different names to the same principles and use of completely divergent content to the same principles. This makes a challenge for good presentation of selected issues for foreign scientists, who are interest in the subject.
} 


\section{noting, that problem if fiscal local autonomy affects every country in which there} is local government ${ }^{5}$.

\footnotetext{
${ }^{5}$ See more examples of research on principle of fiscal local autonomy in various countries at: Friedrich, Peter and Gwiazda, Joanna and Nam, Chang Woon, Development of Local Public Finance in Europe (December 2003). CESifo Working Paper Series No. 1107. Available at SSRN: http:// ssrn.com/abstract=486065 [last visited: 12.01.2016]; see also Erlingsson, Gissur Ó and Ödalen, Jörgen, A Normative Theory of Local Government: Connecting Individual Autonomy and Local Self-Determination with Democracy (2013). APSA 2013 Annual Meeting Paper; American Political Science Association 2013 Annual Meeting. Available at SSRN: http://ssrn.com/abstract=2300654 [12.01.2016]; see also Brueckner, Jan K., Partial Fiscal Decentralization (November 2007). CESifo Working Paper No. 2137. Available at SSRN: http://ssrn.com/abstract=1029581 [last visited: 12.01.2016]; see more Bjornestad, Liv, Fiscal Decentralization, Fiscal Incentives, and Pro-Poor Outcomes: Evidence from Viet Nam (July 1, 2009). Asian Development Bank Economics Working Paper Series No. 168. Available at SSRN: http://ssrn.com/abstract=1616968 or http:// dx.doi.org/10.2139/ssrn.1616968 [last visited: 12.01.2016]; see also Matic, Branko and Markovi, Branimir, Problems of Financing Local and Regional Self-Government. Available at SSRN: http:// ssrn.com/abstract=1144506 [last visited: 12.01.2016]; see also Revelli, Federico and Geys, Benny, Decentralization, Competition and the Local Tax Mix: Evidence from Flanders (January 19, 2009). U. of Torino Department of Economics Research Paper No. 2/2009-GE. Available at SSRN: http://ssrn.com/abstract=1488018 or http://dx.doi.org/10.2139/ssrn.1488018 [last visited: 12.01.2016]; see more Shanske, Darien, Local Fiscal Autonomy Requires Constraints: The Case for Fiscal Menus (October 14, 2013). Stanford Law \& Policy Review, Forthcoming; UC Davis Legal Studies Research Paper No. 356. Available at SSRN: http://ssrn.com/abstract=2340218 [last visited: 12.01.2016]; Haaparanta, Pertti and Juurikkala, Tuuli, Bribes and Local Fiscal Autonomy in Russia (May 4, 2007). BOFIT Discussion Paper No. 12/2007. Available at SSRN: http://ssrn. com/abstract=1001424 or http://dx.doi.org/10.2139/ssrn.1001424 [last visited: 12.01.2016]; see more Chulu, Jimmy, Local Government Financing Framework: A Perspective Review of Zambian Local Governments (December 16, 2014). Journal of Local Government Studies, Volume 1, No. 4, December 2014. Available at SSRN: http://ssrn.com/abstract=2631781 [last visited: 12.01.2015]; see also Turgel, Irina, New Local Self-Government Reform in Russia: A Step to Decentralization or Consolidation of Vertical Authority? (May 15, 2008). 16th NISPAcee Annual Conference 'Public Policy and Administration: Challenges and Synergies', 2008. Available at SSRN: http://ssrn.com/ abstract=2231414 or http://dx.doi.org/10.2139/ssrn.2231414 [last visited: 12.01.2016]; see more Sokolow, Alvin J., The Changing Property Tax in the West: State Centralization of Local Finances. Public Budgeting \& Finance, Vol. 20, Issue 1, Spring 2000. Available at SSRN: http://ssrn.com/ abstract $=234554$ [last visited: 12.01.2016]; see also Вейсалова Х.Ш. Проблема обеспечения финансовой самостоятельности муниципальных образований // Проблемы современной экономики. 2015. № 28-1. URL: http://cyberleninka.ru/article/n/problema-obespecheniya-finan sovoy-samostoyatelnosti-munitsipalnyh-obrazovaniy (дата обращения: 11.02.2016). Научная библиотека КиберЛенинка: http://cyberleninka.ru/article/n/problema-obespecheniya-finansovo y-samostoyatelnosti-munitsipalnyh-obrazovaniy\#ixzz40HTnAxbq [last visited: 11.02.2016]; see also Лагутин И. Б. Принципы регионального финансового контроля и особенности их правового закрепления // Ученые записки. Электронный научный журнал Курского государственного университета . 2011. №1 (17). URL: http://cyberleninka.ru/article/n/ printsipy-regionalnogo-finansovogo-kontrolya-i-osobennosti-ih-pravovogo-zakrepleniya (дата обращения: 11.02.2016). Научная библиотека КиберЛенинка: http://cyberleninka.ru/article/n/ printsipy-regionalnogo-finansovogo-kontrolya-i-osobennosti-ih-pravovogo-zakrepleniya\#ixzz40T4IGvAX [last visited: 12.01.2016].
} 
In modern times, the difficult financial situation of municipalities, which are heavily indebted ${ }^{6}$, highlights problem of fiscal local autonomy more than before. There are serious threats that will be difficulties of some local governments will be not able to implement their commitments. Probably municipal bankruptcy or state nationalization of local government (or acquisitions by another local government) it is only science fiction, because it is not regulated this way in Polish statutes. While there would be probably no other possibilities that to provide additional state funds for local government in exchange of violation of fiscal local autonomy (violation of status quo).

It worth mentioning, that many studies on local government finance use term tax autonomy, in particular this term is used in documents produced by OECD and the IMF. The term "tax autonomy" in the light of OECD reports and other documents captures various aspects of freedom sub-central governments (local government) have over their own taxes. It encompasses features such as sub-central government's right to introduce or to abolish a tax, to set tax rates, to define the tax base, or to grant tax allowances or reliefs to individuals and firms. In a number of countries taxes are not assigned to one specific government level but shared between the central and sub-central governments. Such tax sharing arrangements deny a single sub-central government any control on tax rates and bases, but collectively sub-central governments may negotiate the sharing formula with central government. The wealth of explicit and implicit, statutory and common, institutional arrangements has to be encompassed by a set of indicators that are simultaneously appropriate (they capture the relevant aspects of tax autonomy), accurate (they measure those aspects correctly) and reliable (the indicator set remains stable over time $)^{7}$.

\footnotetext{
${ }^{6}$ See the report of the Supreme Chamber of Control on the debt of local government units at Wykonywanie zadań regionalnych izb obrachunkowych w zakresie przeciwdziałania zagrożeniom wynikającym z nadmiernego zadłużania się jednostek samorządu terytorialnego, Warszawa 2014, source: https://www.nik.gov.pl/plik/id,8484,vp,10578.pdf [last visited: 12.01.2016].

7 See more at OECD Fiscal Decentralisation Database, source: http://www.oecd.org/tax/federalism/oecdfiscaldecentralisationdatabase.htm [last visited: 12.01.2016]; see also edited by V. Ruiz Almendral and F. Vaillancourt, Autonomy in Subnational Income Taxes, Evolving Powers, Existing Practices in Seven Countries, McGill-Queen's University Press (February 1, 2013); Fiscal autonomy of sub-central governments, OECD Network on Fiscal Relations Across Levels of Government, Working paper Nr 2 2005, source: http://www.oecd.org/ctp/federalism/37388375.pdf [last visited: 12.01.2016].
} 


\section{The Constitution of the Republic of Poland - regulations related to fiscal local autonomy}

It is worth noting at the beginning that the problem of fiscal local autonomy the Constitution of Republic of Poland of $2^{\text {nd }}$ April $1997^{8}$ is subject to the European Charter of Local Self-Government ${ }^{9}$, and statutes on the structure of local government units (commune, county, voivodship) ${ }^{10}$. Particular importance should be attributed to the constitutional regulations and the European Charter of Local Self-Government, because they are defining the legal boundaries and other standards for the fiscal local autonomy, what was often emphasized by Polish Constitutional Court in its rulings ${ }^{11}$. According to the scope of this publication, further part of the article is devoted only to constitutional regulations.

The Constitutional of Poland contains the fundamental provisions on the recognition of local government by the state and guarantees of its development. These principles and rules cannot be changed except by adoption of the changes or new constitution. This means that the state assumes the obligation to provide all necessary conditions for the development of local government at Poland. Basis for regulating the local government should have read with Article 2 of the Constitution, according to which the Republic of Poland shall be a democratic state ruled by law and implementing the principles of social justice ${ }^{12}$. This general legal norm outlines the directions of development of the Polish political system and makes special requirement for the legislator that should implement this principle into the statutes. In the sense of the subject and other constitutional regulations, the parliament have the obligation of local government settlement in Poland

\footnotetext{
8 See official translation to English at http://www.sejm.gov.pl/prawo/konst/angielski/kon1.htm [last visited: 12.01.2016]; Dz.U. 1997 nr 78 poz. 483.

9 See more information on official website of Council of Europe, source: http://www.coe.int/en/ web/conventions/full-list/-/conventions/treaty/122 or see also explanatory report on European Charter of Local Self-Government, source: http://www.coe.int/t/congress/sessions/18/Source/ CharteEuropeenne_en.pdf [last visited: 12.01.2016]; Dz.U. 1994 nr 124 poz. 607.

10 See statutes: Act on Commune Self-government, March $8^{\text {th }} 1990$, Dz.U. 1990 nr 16 poz. 95; Act on County Self-Government, June $8^{\text {th }}$ 1998, Dz.U. 1998 nr 91 poz. 578; Act on Voivodship Government, June $5^{\text {th }} 1998$, Dz.U. $1998 \mathrm{nr} 91$ poz. 576.

11 See for example Constitutional Court Judgment March 16th 1999 r. K 35/98; Constitutional Court Judgment October $23^{\text {rd }} 1995$, K 4/95; Constitutional Court Judgment November 11, 1998 K 22/98; Constitutional Court Judgment $21^{\text {st }}$ June, 1999 U 5/98; Constitutional Court Judgment April 12, 2000, K 8/98 and others; see also pod red. C. Kosikowski, J. M. Salachna, Finanse samorządowe. 580 pytań i odpowiedzi, Warszawa 2012, s. 47 - 49, 50.

12 See more legal thoughts on the principle that Poland is a state ruled by law at P. Winczorek, Polska państwem prawnym: ideał a rzeczywistość [w:] G. Ulicka, Wronkowska, Spory wokół teorii i praktyki państwa prawa, Warszawa 2011, source: Lex Omega 2016.
} 
and protect citizens' right of their participation in decision-making of on the level of local government. Conclusion from this is obvious, that in Poland fiscal local autonomy is a constitutional principle that can be realized only through a legal guarantee ${ }^{13}$.

Establishment of local government in Poland results from other constitutional norms, in particular from art. 16 of constitution, according to which, the inhabitants of the units of basic territorial division shall form a self-governing community in accordance with law. Local government shall participate in the exercise of public power. The substantial part of public duties which local government is empowered to discharge by statute shall be done in its own name and under its own responsibility. The subject of a public authority is a local government, which performs tasks assigned by the statutes in its own name and own responsibility. On the basis of and within limits specified by statute, organs of local government and territorial organs of government administration shall enact local legal enactments applicable to their territorially defined areas of operation. The principles of and procedures for enacting local legal enactments shall be specified by statute. This a guarantee for local government autonomy and the core regulation for the content fiscal local autonomy ${ }^{14}$.

Detailed constitutional regulations, which can also be read limits of local government autonomy (also fiscal local autonomy), have been place in Chapter VII of constitution. According to the constitution, local government shall perform public tasks not reserved by the Constitution or statutes to the organs of other public authorities. The commune shall be the basic unit of local government. Other units of regional and/or local government shall be specified by statute. The commune shall perform all tasks of local government not reserved to other units of local government. Units of local government shall possess legal personality. They shall have rights of ownership and other property rights. The self-governing nature of units of local government shall be protected by the courts. Public duties aimed at satisfying the needs of a self- governing community shall be performed by units of local government as their direct responsibility. If the fundamental needs of the State shall so require, a statute may instruct units of local government

\footnotetext{
13 See some thoughts at J. Glumińska-Pawlic, Samodzielność finansowa jednostek samorządu terytorialnego w Polsce. Studium finansowoprawne, Katowice 2003, s. 44 and others.

${ }^{14}$ See also J. Jagoda, Granice samodzielności finansowej jednostek samorządu terytorialnego, FK.2014.1-2.12; see also J. Jagoda, Sądowa ochrona samodzielności jednostek samorządu terytorialnego, LEX 2011, source: Lex Omega 2016, [last visited: 12.01.2016]; see also on boundaries of regulations of local government at M. Bogusz, Konstrukcja upoważnienia do wydania aktu prawa miejscowego a konstrukcja upoważnienia do wydania rozporządzenia, GSP.2005.2.401.
} 
to perform other public duties. The mode of transfer and manner of performance of the duties so allocated shall be specified by statute. The administrative courts shall settle jurisdictional disputes between units of local government and units of government administration ${ }^{15}$.

The most important constitutional legal norm for the analysis of fiscal local autonomy is article 167, according to which units of local government shall be assured public funds adequate for the performance of the duties assigned to them. The revenues of units of local government shall consist of their own revenues as well as general subsidies and specific grants from the state budget. The sources of revenues for units of local government shall be specified by statute. Alterations to the scope of duties and authorities of units of local government shall be made in conjunction with appropriate alterations to their share of public revenues. To the extent established by statute, units of local government shall have the right to set the level of local taxes and charges. Units of local government shall perform their duties through constitutive and executive organs ${ }^{16}$.

\section{Conclusion}

It must be admitted that the legal analysis without data analysis has little influence reality and can't provide objective conclusions. We can state the fact that the legislator in the Constitution of Poland establishes a broad range of legal possibilities in the field of fiscal local autonomy as a whole, but effective functioning of such a system put us in doubt. In fact, we do have in largest proportion funds provided by the state to the local government and does not look like that it is going to change in near future ${ }^{17}$. The proclamation in legal acts (also in constitution) of fiscal local autonomy is a kind of modern understanding and concept of local government. However, any principle or concept will be worthless, until it is not supported by the economic means. Therefore, it is clear that local authorities will be independent in fact, only in the case of fixed (real) financial guarantees of inde-

\footnotetext{
15 See comments at T. Dębowska-Romanowska, O pojęciu "spraw finansowych" w rozumieniu art. 171 ust. 2 Konstytucji, GSP.2007.1.43

${ }^{16}$ See comments at W. Gonet, Zakres swobody zawierania umów przez jednostki samorządu terytorialnego, LEX 2011, source: Lex Omega 2016 [last visited: 12.01.2016]; see also A. Niezgoda, Adekwatność i proporcjonalność jako reguły podziału zasobów publicznych, Podział zasobów publicznych między administrację rządową i samorządową, Lex 2012, source: Lex Omega 2016, [last visited: 12.01.2016].

17 See data analizys at J. Łukomska- Szarek, Analiza wskaźnikowa w procesie zarządzania finansów samorządów lokalnych, Studia i Materiały. Miscellianea Oeconomicae nr 12/2012, source: http:// miscellanea.ujk.edu.pl/data/Oferta/Pliki/311_23__ukomska.pdf [last visited: 12.01.2016]
} 
pendence. By the way, in Poland system worked for many years; maybe it is easier and better for the state not to have enough fiscal autonomy on local government level or perhaps the author's conclusions are wrongful, because a different view is also present in the literature. That principle of fiscal local autonomy should not be simplified that way, as an expression not to be subject to non-anyone's power and help ${ }^{18}$. In addition, even as it presented above, that fiscal local autonomy in Polish Constitution, which indicates that the revenues of local government shall consist of their own revenues as well as general subsidies and specific grants from the state budget. In turn, it could be a rhetoric question, whether in the light of modern public finance the grant by itself as financial institution, which deprives financial autonomy of local government.

\section{Literature:}

1. Act on Commune Self-government, March $8^{\text {th }}$ 1990, Dz.U. $1990 \mathrm{nr} 16$ poz. 95;

2. Act on County Self-Government, June $8^{\text {th }} 1998$, Dz.U. $1998 \mathrm{nr} 91$ poz. 578;

3. Act on Voivodship Government, June 5 ${ }^{\text {th }} 1998$, Dz.U. $1998 \mathrm{nr} 91$ poz. 576.

4. Autonomy - the right or condition of self-government: between the First and Second World Wars, Canada gained greater autonomy from Britain, Oxford Dictionaries, source: http://www.oxforddictionaries.com/definition/english/autonomy

5. Bjornestad, Liv, Fiscal Decentralization, Fiscal Incentives, and Pro-Poor Outcomes: Evidence from Viet Nam (July 1, 2009). Asian Development Bank Economics Working Paper Series No. 168. Available at SSRN: http://ssrn.com/abstract=1616968 or http:// dx.doi.org/10.2139/ssrn. 1616968

6. Bogusz M., Konstrukcja upoważnienia do wydania aktu prawa miejscowego a konstrukcja upoważnienia do wydania rozporządzenia, GSP.2005.2.401

7. Brueckner, Jan K., Partial Fiscal Decentralization (November 2007). CESifo Working Paper No. 2137. Available at SSRN: http://ssrn.com/abstract=1029581

8. Chulu, Jimmy, Local Government Financing Framework: A Perspective Review of Zambian Local Governments (December 16, 2014). Journal of Local Government Studies, Volume 1, No. 4, December 2014. Available at SSRN: http://ssrn.com/ abstract $=2631781$

9. Constitutional Court Judgment $21^{\text {st }}$ June, 1999 U 5/98;

10. Constitutional Court Judgment April 12, 2000, K 8/98

11. Constitutional Court Judgment March 16th 1999 r. K 35/98;

\footnotetext{
18 Por. E. Kornberger-Sokołowska, Zasada proporcjonalności a ochrona samodzielności finansowej jednostek samorządu terytorialnego [w:] Prawo finansowe samorządu terytorialnego. Prawo finansowe wobec wyzwań XXI wieku pod red. J. Glinieckiej, E. Juchniewicza, T. Sowińskiego, M. Wróblewskiej, Warszawa 2013, s. 37; see A. Jurkowska-Zeidler, Charakter prawny dotacji celowej na zadania zlecone z zakresu administracji rządowej w świetle orzecznictwa, GSP.2015.2.289
} 
12. Constitutional Court Judgment November 11, 1998 K 22/98;

13. Constitutional Court Judgment October $23^{\text {rd }} 1995$, K 4/95;

14. Dębowska-Romanowska T., O pojęciu „spraw finansowych” w rozumieniu art. 171 ust. 2 Konstytucji, GSP.2007.1.43

15. Erlingsson, Gissur Ó and Ödalen, Jörgen, A Normative Theory of Local Government: Connecting Individual Autonomy and Local Self-Determination with Democracy (2013). APSA 2013 Annual Meeting Paper; American Political Science Association 2013 Annual Meeting. Available at SSRN: http://ssrn.com/abstract=2300654

16. Explanatory report on European Charter of Local Self-Government, source: http:// www.coe.int/t/congress/sessions/18/Source/CharteEuropeenne_en.pdf Dz.U. 1994 nr 124 poz. 607.

17. Fiscal Decentralisation Database, source: http://www.oecd.org/tax/federalism/oecdfiscaldecentralisationdatabase.htm [last visited: 12.01.2016]; see also edited by V. Ruiz Almendral and F. Vaillancourt, Autonomy in Subnational Income Taxes, Evolving Powers, Existing Practices in Seven Countries, McGill-Queen's University Press (February 1, 2013); Fiscal autonomy of sub-central governments, OECD Network on Fiscal Relations Across Levels of Government, Working paper Nr 2 2005, source: http://www.oecd.org/ctp/federalism/37388375.pdf [last visited: 12.01.2016].

18. Friedrich, Peter and Gwiazda, Joanna and Nam, Chang Woon, Development of Local Public Finance in Europe (December 2003). CESifo Working Paper Series No. 1107. Available at SSRN: http://ssrn.com/abstract $=486065$

19. Glumińska-Pawlic J., Samodzielność finansowa jednostek samorządu terytorialnego w Polsce. Studium finansowoprawne, Katowice 2003

20. Gonet W., Zakres swobody zawierania umów przez jednostki samorządu terytorialnego, LEX 2011, source: Lex Omega 2016

21. Haaparanta, Pertti and Juurikkala, Tuuli, Bribes and Local Fiscal Autonomy in Russia (May 4, 2007). BOFIT Discussion Paper No. 12/2007. Available at SSRN: http://ssrn. com/abstract=1001424 or http://dx.doi.org/10.2139/ssrn.1001424

22. Jagoda J., Granice samodzielności finansowej jednostek samorządu terytorialnego, FK.2014.1-2.12;

23. Jagoda J., Sądowa ochrona samodzielności jednostek samorządu terytorialnego, LEX 2011, source: Lex Omega 2016

24. Jurkowska-Zeidler A., Charakter prawny dotacji celowej na zadania zlecone z zakresu administracji rządowej w świetle orzecznictwa, GSP.2015.2.289

25. Kornberger-Sokołowska E., Zasada proporcjonalności a ochrona samodzielności finansowej jednostek samorządu terytorialnego [w:] Prawo finansowe samorządu terytorialnego. Prawo finansowe wobec wyzwań XXI wieku pod red. J. Glinieckiej, E. Juchniewicza, T. Sowińskiego, M. Wróblewskiej, Warszawa 2013;

26. Kosikowski C., Salachna J. M., red. Finanse samorządowe. 580 pytań i odpowiedzi, Warszawa 2012 
27. Łukomska- Szarek J., Analiza wskaźnikowa w procesie zarządzania finansów samorządów lokalnych, Studia i Materiały. Miscellianea Oeconomicae nr 12/2012, source: http://miscellanea.ujk.edu.pl/data/Oferta/Pliki/311_23_ukomska.pdf

28. Matic, Branko and Markovi, Branimir, Problems of Financing Local and Regional Self-Government. Available at SSRN: http://ssrn.com/abstract=1144506

29. Michael E. Libonati, Local Government Autonomy, Louisiana Law Review Volume 62 | Number 1 Fall 2001, source: http://digitalcommons.law.lsu.edu/cgi/viewcontent. cgi?article $=5914 \&$ context $=$ lalrev

30. Niezgoda A., Adekwatność i proporcjonalność jako reguły podziału zasobów publicznych, Podział zasobów publicznych między administrację rządową i samorządową, Lex 2012, source: Lex Omega 2016

31. Ödalen J., A Normative Theory of Local Government: Connecting Individual Autonomy and Local Self-Determination with Democracy, Prepared for the American Political Science Association Annual Meeting and Exhibition, August 29-September 1, 2013, Chicago, Illinois. source: https://www.academia.edu/4174425/A_Normative_ Theory_of_Local_Government_Connecting_Individual_Autonomy_and_Local_ Self-Determination_with_Democracy

32. Revelli, Federico and Geys, Benny, Decentralization, Competition and the Local Tax Mix: Evidence from Flanders (January 19, 2009). U. of Torino Department of Economics Research Paper No. 2/2009-GE. Available at SSRN: http://ssrn.com/ abstract=1488018 or http://dx.doi.org/10.2139/ssrn.1488018

33. Shanske, Darien, Local Fiscal Autonomy Requires Constraints: The Case for Fiscal Menus (October 14, 2013). Stanford Law \& Policy Review, Forthcoming; UC Davis Legal Studies Research Paper No. 356. Available at SSRN: http://ssrn.com/ abstract $=2340218$

34. Sokolow, Alvin J., The Changing Property Tax in the West: State Centralization of Local Finances. Public Budgeting \& Finance, Vol. 20, Issue 1, Spring 2000. Available at SSRN: http://ssrn.com/abstract=234554 [last visited: 12.01.2016];

35. Supreme Chamber of Control on the debt of local government units at Wykonywanie zadań regionalnych izb obrachunkowych $\mathrm{w}$ zakresie przeciwdziałania zagrożeniom wynikającym z nadmiernego zadłużania się jednostek samorządu terytorialnego, Warszawa 2014, source: https://www.nik.gov.pl/plik/id,8484,vp,10578.pdf

36. Turgel, Irina, New Local Self-Government Reform in Russia: A Step to Decentralization or Consolidation of Vertical Authority? (May 15, 2008). 16th NISPAcee Annual Conference 'Public Policy and Administration: Challenges and Synergies', 2008. Available at SSRN: http://ssrn.com/abstract=2231414 or http://dx.doi.org/10.2139/ ssrn.2231414

37. Winczorek P., Polska państwem prawnym: ideał a rzeczywistość [w:] G. Ulicka, Wronkowska, Spory wokół teorii i praktyki państwa prawa, Warszawa 2011, source: Lex Omega 2016 
38. Вейсалова Х.Ш. Проблема обеспечения финансовой самостоятельности муниципальных образований // Проблемы современной экономики. 2015. № 28-1. URL: http://cyberleninka.ru/article/n/problema-obespecheniya-finan sovoy-samostoyatelnosti-munitsipalnyh-obrazovaniy (дата обращения: 11.02.2016). Научная библиотека КиберЛенинка: http://cyberleninka.ru/article/n/problem a-obespecheniya-finansovoy-samostoyatelnosti-munitsipalnyh-obrazovaniy\#ixzz $40 \mathrm{H}$ TnAxbq

39. Лагутин И. Б. Принципы регионального финансового контроля и особенности их правового закрепления // Ученые записки. Электронный научный журнал Курского государственного университета . 2011. №1 (17). URL: http:// cyberleninka.ru/article/n/printsipy-regionalnogo-finansovogo-kontrolya-i-osobenn osti-ih-pravovogo-zakrepleniya (дата обращения: 11.02.2016). Научная библиотека КиберЛенинка: http://cyberleninka.ru/article/n/printsipy-regionalnogo-finans ovogo-kontrolya-i-osobennosti-ih-pravovogo-zakrepleniya\#ixzz40T4IGvAX 